\title{
In Appreciation of John Gronbeck-Tedesco
}

\section{Kent Neely}

John Gronbeck-Tedesco and I first met almost twenty years ago in Kansas City at a Mid-America Theatre Conference. I had delivered a paper about Lee Breuer, and John asked whether he could publish it in the Journal of Dramatic Theory and Criticism. A piece I wrote about Martha Clarke had appeared earlier, but I had not met John in person. I can still recall his modest yet energetic disposition and the genuine interest he had in my work. That initial conversation would grow into a relationship that has continued for almost two decades. I am indebted to John, and I believe all involved in theatre scholarship are indebted as well.

John approached me in fall 1992 about serving as the Journal performance section editor. Like other conversations I had with him, John was enthusiastic about the possibilities, and he encouraged me to make the section a space for the "connection and collision" of ideas about performance. I asked whether I could rename the section. I thought the name should suggest that the contents would be rooted in documenting and commenting about performance, and I hoped the items would provide, I hoped, a practical reference for other scholars. John instantly agreed and, thereafter, the performance section was called "Praxis."

The first "Praxis" section appeared in the spring 1993 issue. I condintued to edit that section through fall 1999. Along the way, I was able to include some marvelous pieces that ranged from performance reviews of classic plays (such as "Le Tartuffe as performed by Le Théâtre du Soleil" by Mark Jennison, fall 1996) to commentaries about troupes that were at the leading edge of performance (like "Dilating the Body, Transporting the Mind: Considering Primus Theatre" by Per Brask, fall 1994). John provided me free rein to include whatever I felt made a meaningful contribution to the body of theatre theory and criticism. That support was appreciated then. I now know how rare it was.

John's editorial leadership of the Journal was distinguished, in part, by the special supplements that were regularly included. I still marvel at those sections because they covered the current critical discourse and provided a forum, and now a chronicle, of thought. Many deserve another review, in particular: "Theatre Historiography" (spring 1989), "Physics and the New Historiography" (spring 1991), "Feminist/Dramatic Theory" (spring 1995), and "Homage to Tadeusz Kantor" (fall 1995). These are important essay collections that help us understand the arc of thought that has occurred over the last twenty years.

Kent Neely is the Dean of the College of Arts and Sciences at Southern Illinois University Edwardsville. 
I had the pleasure of editing a special supplement in 1997, "Death: (Re)Presenting Mortality and Morbundity." That collection fulfilled a desire I had to provide an exchange of thought about performances that covered the end of life. I had many excellent submissions to choose from. Those that were published offered unique views of performance, personal experience, and accounts of historical importance. It gave me further appreciation for John's encouraging style that produced so many excellent editions over a long period of time.

On the occasion of John's departure as editor, those of us who had pieces appear in JDTC should extend our gratitude to him and acclaim to current and future scholars that they are indebted to John for creating a space of discourse that they build upon. 